\author{
Joanna Panasiuk \\ Faculty of Artes Liberales \\ University of Warsaw \\ Warsaw \\ joanna_panasiuk@o2.pl
}

In memory of Prof. Stefan Nieznanowski

\title{
Late Baroque Manuscript "Supplication of a Sinner to the Lord Jesus". Eschatological Reflections ${ }^{1}$
}

\begin{abstract}
The scope of observations in this article is defined by the "Supplication of a Sinner to the Lord Jesus" (including "Jesus, my merciful ..."), belonging to the so-called popular trend. This text was found in a handwritten collection dated to 1744, belonging to the Discalced Carmelite Nuns in Kraków. In this song, as a result of eschatological reflections we can identify the idea of contemptus mundi (contempt of the world) originating from the Middle Ages.
\end{abstract}

Keywords: Baroque, Catholicism, contemptus mundi.

\footnotetext{
1 I analysed this text in my doctoral dissertation defended in 2013 in Lublin at Maria Sklodowska-Curie University.

I prepared my PhD under the direction of Prof. Stefan Nieznanowski who passed away on 26 June 2018.

I dedicate my article to the memory of Prof. Stefan Nieznanowski.

This is an Open Access article distributed under the terms of the Creative Commons Attribution 3.0 PL License (creativecommons.org/licenses/by/3.0/pl/), which permits redistribution, commercial and non-commercial, provided that the article is properly cited. (C) The Author(s), 2018

Publisher: Institute of Slavic Studies, Polish Academy of Sciences

Editor-in-chief: Jolanta Sujecka

Conception and academic editing of this issue: Maciej Falski, Tomasz Rawski, Jolanta Sujecka with the collaboration of Ewa Niedziałek
} 
7 he subjects of grief, repentance and God's anger are familiar themes

1 in the literature of old Europe. At the time there were many works on the theme of the Last Judgment. Their role was to create a feeling of fear and terror, as well as to induce people to adopt an attitude focused on saving their souls. In fact, the penitential stylization of numerous 17thand 18th-century texts was a response to the Counter-Reformation. Then, among other things, literature tried to propagate confessional content and the penitential model of life with increased strength (Nowicka-Jeżowa, 2016a, pp. 7-17; Okoń, 1980, pp. LIV-LV).

The scope of observations in this article is defined by the "Supplication of a Sinner to the Lord Jesus" (including "Jesus, my merciful ..."), ${ }^{2}$ belonging to the so-called popular trend. This text was found in a handwritten collection dated to 1744, belonging to the Discalced Carmelite Nuns in Kraków. In this song, as a result of eschatological reflections we can identify the idea of contemptus mundi (contempt of the world) connected with Christian teachings of the 17th century originating from the Middle Ages.

At the beginning of the supplication the lyrical subject of the poem reveals an awareness of his sinfulness. This is the cause of his unhappiness, because he will not be able to go to heaven. His life was one of debauchery, which, unfortunately, cannot be hidden from God. In order to illustrate this situation, he uses a pun:

Czeka mie ogień wieczny,

A jam przecie bezpieczny,

Lecz jak Ciebie przejednam,

Gdy się z światem pożegnam?

The penitent, observing his own interior, knows that he will be condemned for his bad behaviour, even if he feels safe because he believes in God's mercy and the grace of forgiveness, as we can read: "to the abundance of sin God responds with extraordinary grace". ${ }^{3}$ For this reason the following sentence appears, which is also a rhetorical question: how

\footnotetext{
2 Pieśni różne, wyjęte z różnych kancjonałów, o Bożym Narodzeniu i Męce Pańskiej i insze, wszelkiego czasu stużące, w jedno zebrane Roku Pańskiego 1744 na chwałę Panu Bogu i Pannie Przenajświętszej (1744), Manuscript, Discalced Carmelite Nuns Library, Kraków, Wesoła, No. 112, p. 127 (Microfilm No. 2678 in the Microfilm Archive - Institute of Church Archives, Libraries and Museums - John Paul II Catholic University, Lublin; reference ABMK 2678).

3 Sentence: G. Raubo, 1997, p. 142.
} 
can you "bribe" God - "how do I mollify you?" - in order to be taken to paradise? With this sentence the lyrical subject doubts in the possibility of his receiving a happy life after death.

The sinner is conducting a retrospective analysis of his life and ends it with self-accusation: he has sinned an entire age (he is an elderly man), he believed in worldly happiness:

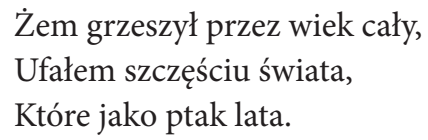

He has a tendency to accuse himself of wrong choices that were due to his enjoying life. It is in this approach to existence that the drama manifests itself, because according to the spirit of some religious currents during the Counter-Reformation, engaging in affairs of the world was wrong because it drew people away from salvation. Such a perception of earthly reality, according to the idea of contemptus mundi, seems to build a specific system of values based on isolation from ordinary human life (Gruchała, 1997, pp. 33-43). Withdrawal from the world, giving up all pleasure, has to lead to the contemplation of religious values, because faith is the foundation of all virtues.

The sentences in this poem are postulatory in nature. They attempt to show the path leading to salvation, and to convince readers to apply themselves to overcoming temptation. However, the poem's lyrical situation is paradoxical and mysterious. Despite sentences that speak about the greatness of God and the possibilities of centuries-long torture for sinners, the atmosphere that we perceive here is calm and peaceful:

Grzechem obrażałem Ciebie,

Niegodzien-em być w niebie.

Ach moje utrapienie,

Żem rozkoszą zwiedziony,

$\cdots$

Z grzechów mych wielkie brzemię,

...

Czeka mnie ogień wieczny,

A jam przecie bezpieczny

$\ldots$ 


\section{Joanna Panasiuk}

It is only the final part of the text that provides information about the legitimate possibility of God's real anger because of the sinner's evil deeds. The Creator, however, does not send punishment, and the mortal, despite his bad behaviour, misses God. He wants to have a clear conscience, eternal peace after death, because he has reached the conclusion that the bond with the Transcendent is irreplaceable.

The same atmosphere of anxiety and self-accusation is introduced by Kasper Miaskowski in Elegia pokutna do Pana i Boga w Trójcy Jedynego and by Jan Andrzej Morsztyn in Pokuta w kwartanie. These works are built on the same penitential patterns. The horror of the subject, despising himself like David in Psalm 50, is intensified by approaching death. Calmness is introduced only by the image of Jesus who "annulled the sins of the world" (Backvis, 2003, p. 44).

In the final part, the analysed work refers to lamentum penitentiale or versus de penitentia, the well-known penitential lamentation from Latin medieval Europe. In this kind of text, like here, the sinner lost his way spiritually during his life and then received the grace of conversion. Shortly before his death, he confessed his sins, repented of them and begged God for forgiveness. In the presented considerations, we can observe this kind of spiritual wandering and then conversion.

The confession of sins plays the role of the loci communis of all genres that include the theme of parting with the world, such as the lamentum penitentiale mentioned above or ars moriendi. The provenance of the genre should be sought in biblical penitential psalms or in the sacrament of confession (Michałowska, 1996, pp. 502-507).

In conclusion, it was not a new idea to use eschatological issues, both in monastic settings and in the context of Old Polish literature. A tendency to exploit old biblical motifs responded to the needs of late Baroque audiences (Nowicka-Jeżowa, 2016b, pp. 41-58). 


\section{References}

Backvis, C. (2003). Panorama poezji polskiej okresu baroku (A. Nowicka-Jeżowa \& R. Krzywy, Eds., G. Majcher, Trans.) (Vol. 1). Warszawa: Wydawnictwo Optima.

Gruchała J. S. (1997). Wstęp. In. Mikołaj Sęp Szarzyński. Poezje (J. S. Gruchała, Ed.). Kraków: Biblioteka Polska.

Hanusiewicz-Lavallee, M. (2016). Dawne i nowe: Tożsamość wyznaniowa katolików świeckich w potrydenckiej Rzeczypospolitej. In J. Dąbkowska-Kujko (Ed.), Formowanie kultury katolickiej w dobie potrydenckiej: Powszechność i narodowość katolicyzmu polskiego (pp. 103-144). Warszawa: Wydawnictwo UW.

Kopeć, J. J. (1981). Nurt pasyjny w średniowiecznej religijności polskiej. In H. D. Wojtyska \& J. J. Kopeć (Eds.), Męka Chrystusa wczoraj i dziś (pp. 49-57). Lublin: Katolicki Uniwersytet Lubelski.

Michałowska, T. (1996). Średniowiecze. Warszawa: PWN.

Morsztyn, Z. (1954). Muza domowa (J. Dürr-Durski, Ed.) (Vol. 2). Warszawa: PIW.

Nieznanowski, S. (1965). O poezji Kaspra Miaskowskiego: Studium o ksztattowaniu sie baroku w poezji polskiej. Lublin: TN KUL.

Nowicka-Jeżowa, A. (2016a). Drogi duchowe katolicyzmu polskiego na mapie potrydenckiej Europy - spojrzenie wstępne. In A. Nowicka-Jeżowa (Ed.), Drogi duchowe katolicyzmu polskiego XVII wieku (pp. 7-17). Warszawa: Wydawnictwo UW.

Nowicka-Jeżowa, A. (2016b). Pokolenia trydenckie między tradycją a wyzwaniami przyszłości. In J. Dąbkowska-Kujko (Ed.), Formowanie kultury katolickiej w dobie potrydenckiej: Powszechność i narodowość katolicyzmu polskiego (pp. 21102). Warszawa: Wydawnictwo UW.

Okoń J. (1980). Wstęp. In. Samuel Twardowski. Nadobna Paskwalina (J. Okoń, Ed.). Wrocław: BN.

Pieśni różne, wyjęte z różnych kancjonałów, o Bożym Narodzeniu i Męce Pańskiej i insze, wszelkiego czasu służace, w jedno zebrane Roku Pańskiego 1744 na chwałe Panu Bogu i Pannie Przenajświętszej. (1744). Manuscript, Discalced Carmelite Nuns Library, Kraków, Wesoła, no. 112, p.127 (Microfilm no. 2678 in Microfilm Archive - Institute of Church Archives, Libraries and Museums - John Paul II Catholic University, Lublin; reference ABMK 2678).

Raubo, G. (1997). Barokowy świat człowieka: Refleksja antropologiczna w twórczości Stanisława Herakliusza Lubomirskiego. Poznań: WiS.

Discalced Carmelite Nuns Library [Biblioteka Karmelitanek Bosych], Kraków, Wesoła, manuscript no. 112, p. 127; (Microfilm no. 2678 in Microfilm Archive - Institute of Church Archives, Libraries and Museums - John Paul II Catholic University, Lublin; reference ABMK 2678). 


\section{Transcription of the text}

\section{Suplika grze[sznika] do Pana Jezusa}

Jezu mój litościwy,

Ja człowiek nieszczęśliwy,

Grzechem obrażałem Ciebie,

Niegodzien-em być w niebie.

Skarży się na mię sumnienie.

Ach, moje utrapienie,

Żem rozkoszą zwiedziony,

Marnością zaślepiony,

Choćbym się skrył pod ziemię,

$\mathrm{Z}$ grzechów mych wielkie brzemię.

[...] się nic może

Przed okiem Twoim Boże.

Czeka mnie ogień wieczny,

A jam przecie bezpieczny,

Lecz jak Ciebie przejednam,

Gdy się z światem pożegnam?

Czuło to serce moje

I wieczne niepokoje

[...] duszę miały,

Żem grzeszył przez wiek cały.

Ufałem szczęściu świata,

Które jako ptak lata,

Łagodnie przylatuje,

$\mathrm{Z}$ [d]radliwie odlatuje.

Ach, dość niestatku mego,

Do Ciebie Pana mego 
Garnę się utrapiony,

Bym nie był zatracony.

[...] mnie możesz ożywić

Chociam nie chciał sprzeciwić.

Możesz przebaczyć winy,

Gniewu Twego przyczyny.

Boże mój litościwy,

Ja człowiek nieszczęśliwy.

Jako ryba do wody

Do twojej wrę ochłody.

Rybie bez wody nudno,

A mnie bez Ciebie trudno.

O Jezu mój kochany,

O zdroju nieprzebrany,

Jeleń się do potoku

Kwapi, a ja do boku

I Ran Twych, gdzie strumienie

Płyną na me zbawienie.

Przez twe gorzkie skonanie,

Daj mi z grzechów powstanie.

Przez zmartwychwstanie Twoje,

Daj niebieskie pokoje. A[men]

\section{Późnobarokowy rękopis „Supliki grzesznika do Pana Jezusa". Eschatologiczne refleksje}

Zakres obserwacji wyznaczy tu należąca do nurtu tzw. popularnego pieśń Suplika grzesznika do Pana Jezusa (inc. „Jezu mój litościwy...”). Tekst odnaleziono w rękopiśmiennym zbiorze datowanym na 1744 rok, należącym do biblioteki karmelitanek bosych w Krakowie. W pieśni - na skutek eschatologicznych refleksji - uobecnia się idea contemptus mundi (pogardy świata), wywodząca się z wieków średnich.

Słowa kluczowe: barok, katolicyzm, contemptus mundi. 


\section{Note}

Joanna Panasiuk, Faculty of Artes Liberales, University of Warsaw, Warsaw. joanna_panasiuk@o2.pl

The preparation of the article was self-funded by the author.

No competing interests have been declared. 